\title{
Studi Pemanfaatan Abu Tanah Liat Bakar Asal Gunung Sarik Padang Sebagai Filler Pada Campuran Hot Rolled Sheet (HRS) - WC
}

\author{
Study is to Evaluate the Impact of Substitution of Standard Filler of HRS-WC \\ with Clay Mineral from Gunung Sarik Padang
}

\section{Fauna Adibroto}

Jurusan Teknik Sipil Politeknik Negeri Padang Kampus Limau Manis Padang

Telp. 0751-72590 Fax. 0751-72576 Email: fauna_adibroto@yahoo.com

\begin{abstract}
Together with advancement in transportation technology, there is a need to study current technology on transportation. Various research have been conducted on pavement to achieve a strong, durable, and economic construction. One of the constructions is Hot Rolled Sheet - Wearing Course (HRS-WC) or widely known as thin concrete asphaltic layer. Concrete asphalt is a flexible pavement with high structural strength and widely used in Indonesia as road pavement. Therefore the characteristic of the mixture is highly affected by type and percentage of filler in the mixture. In the last two decades, design methods are developed based on analytical method which require stiffness modulus and structural values of the material. During this period many research have been conducted on the methods to improve performance of asphaltic concrete by modification of materials as well as material substitution.

The main objective of this study is to evaluate the impact of substitution of standard filler of HRS-WC with clay mineral from Gunung Sarik, Padang, on Marshall properties parameters such as stability, density, VIM, VMA, $V F B$, flow, and MQ. This aim is achieved by analyzing Marshall properties of the mixtures.

Our study shows that the substitution of standard filler with clay mineral from Gunung Sarik with variations from 25\%, 50\%, 75\%, and 100\% has no significant impact on optimum asphalt content and other Marshall properties such as Density, VIM, VMA, and Flow. These values do not vary from mixtures using standard filler.
\end{abstract}

Keywords : HRS-WC, Fller, clay, Marshall

\section{PENDAHULUAN}

Menyangkut perkerasan jalan, campuran beraspal adalah merupakan material yang sering dipakai untuk melapisi permukaan jalan, contohnya seperti campuran Asphalt Concrete (AC) yang dikenal dengan beton aspal, Hot Rolled Sheet (HRS) atau lapis tipis aspal beton , Split Mastic Asphalt (SMA), dan lain sebagainya, dimana yang membedakan campuran tersebut adalah komposisi gradasi agregatnya serta jumlah kadar aspalnya. Beberapa faktor penting yang harus diperhatikan dari campuran beraspal antara lain adalah kemampuan memikul beban tanpa mengalami kerusakan (stabilitas), kemampuan bertahan tanpa mengalami kehancuran terhadap waktu pelayanan (durabilitas), kelenturan atau fleksibilitas, ketahanan terhadap kelelahan (fatique resistance), kekesatan permukaan atau ketahanan geser, kedap air, dan sifat mudah dikerjakan (workability).

Penggunaan filler (material pengisi) yang paling sering digunakan untuk campuran beraspal adalah abu batu, yang merupakan hasil bawaan dari proses pemecahan batu oleh alat stone crusher sehingga sedikit yang bisa diperoleh. Sebagai alternatif pengganti yang abu batu sebagi filler yang sering digunakan adalah filler semen, tetapi dibeberapa daerah sulit didapatkan dan harganya relatif mahal. Beberapa perusahaan yang bergerak dibidang proyek konstruksi jalan umumnya menghendaki bahan filler yang mudah didapatkan, ekonomis dan menggunakan bahan lokal sebagai bahan alternatif.

Dalam rangka memenuhi harapan tersebut, maka dicoba melakukan penelitian salah satu bahan lokal sebagai alternatif pengganti filler yaitu abu yang berasal dari tanah liat bakar. Dimana selama ini sesungguhnya tanah liat sudah 
dimanfaatkan sebagai bahan dasar pembuatan bata, genteng, gerabah dan lain sebagainya, bahkan sering juga tanah liat digunakan sebagai bahan timbunan. Sementara potensi deposit tanah liat cukup banyak khususnya di Sumatera Barat yang terdapat di beberapa tempat dalam bentuk gundukan bukit, seperti di Gunung Sarik Padang, Lubuk Alung, Payakumbuh dan sebagainya.

Apakah mungkin campuran beraspal yang menggunakan filler yang berasal dari abu tanah liat bakar dapat menghasilkan campuran beraspal yang layak untuk perkerasan jalan? Harapan pernyataan tersebut dapat terjawab melalui serangkaian penelitian, sehingga diperoleh bahan perkerasan jalan khususnya filler yang dapat menggantikan material standar yang memenuhi spesifikasi yang telah ditetapkan.

\section{Perkerasan Jalan}

Perkerasan jalan adalah suatu lapisan yang terletak di atas tanah yang telah mengalami pemadatan dan mempunyai fungsi untuk mendukung beban lalulintas yang kemudian menyebarkannya ke badan jalan supaya tanah dasar tidak menerima beban yang lebih besar daripada daya dukung tanah dasar yang diizinkan. Sebelum mengalami perkembangan lebih lanjut konstruksi perkerasan jalan dibagi menjadi tiga jenis yaitu :

1. Perkerasan Lentur (Flexible Pavement), dengan bahan ikat perkerasan ini adalah aspal.

2. Perkerasan Tegar (Rigid Pavement), dengan bahan ikat perkerasan ini adalah Semen Portland.

\section{Perkerasan Gabungan (Composite Pavement), adalah merupakan gabungan antara perkerasan lentur dan kaku.}

Perencanaan perkerasan dapat dikelompokkan menjadi :

a. Structural Pavement Design
Yaitu menentukan tebal perkerasan dan bagian-bagiannya, misalnya :

Tebal lapis permukaan, fondasi, slab beton, dan sebagainya.

b. Paving Mixture Design

Yaitu menentukan jenis dan kualitas bahan yang akan digunakan untuk lapis-lapis perkerasan, misal :

- Persyaratan aspal

- Persyaratan batu

- Kualitas beton aspal, dan lainlain.

Untuk menyiapkan perkerasan perlu dipertimbangkan hal-hal sebagai berikut :

a. Kinerja / Performance perkerasan Hal ini berkaitan dengan lalu lintas, yaitu :

- Volume lalu lintas

- Beban gandar kendaraan yang akan dilewatinya.

b. Umur rencana perkerasan

Umur rencana adalah waktu dalam tahun dihitung sejak perkerasan (jalan) dibuka untuk lalu lintas sampai saat diperlukan perbaikan berat. Selama umur rencana ini, perkerasan diharapkan bebas dari pekerjaan perbaikan berat.

c. Kondisi awal dan kondisi akhir perkerasan

Yaitu berkaitan dengan kondisi perkerasan (cacat/kerusakan) pada awal umur rencana dan tingkat perkerasan yang masih dapat diterima pada akhir umur rencana.

Pada penelitian ini perkerasan jalan yang dimaksud adalah lapis keras lentur dimana lapis perkerasan lentur terdiri atas tiga bagian, lihat Gambar 1.

1. Lapis fondasi bawah (subbbase course).

2. Lapis fondasi atas (base course).

3. Lapis fondasi permukaan (surface course).

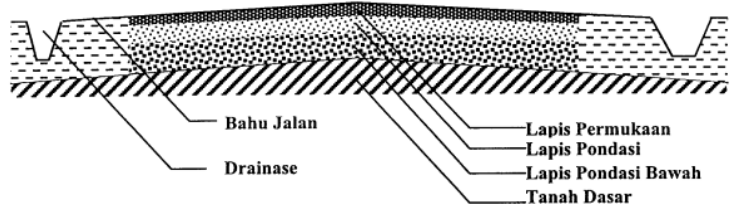




\section{Gambar 1 Komponen Umum Perkerasan lentur}

Tiap bagian dari lapis keras mempunyai fungsi yang berbeda-beda. Pada lapis keras lentur fungsi lapis permukaan yaitu :

1. Memberikan suatu permukaan jalan yang rata.

2. Menahan gaya geser dari beban roda.

3. Sebagai lapis aus.

4. Sebagai lapis kedap air untuk melindungi lapisan di bawahnya.

\section{a. Karakteristik Perkerasan}

Suatu lapis keras jalan dikatakan baik apabila mempunyai stabilitas tinggi, fleksibilitas tinggi, durabilitas tinggi, skid resistance yang cukup, dan mudah dalam pekerjaan (workability). Selain itu perkerasan juga harus memberikan kenyamanan bagi lalu lintas yang lewat, serta biaya pembuatan dan pemeliharaan yang relatif murah. Sifat-sifat tersebut dapat diterangkan sebagai berikut :

\section{b. Hot Rolled Sheet (HRS)}

Campuran Hot Rolled Sheet merupakan suatu campuran bergradasi senjang (gap graded) dimana kekuatannya tergantung pada kekuatan mortarnya (campuran agregat halus, filler dan aspal) sedangkan aspal beton merupakan suatu campuran bergradasi menerus (continuous graded) yang kekuatannya tergantung pada ikatan antar agregat dan aspal. HRS merupakan campuran yang lebih banyak menggunakan agregat halus sehingga memerlukan suatu kadar aspal yang lebih tinggi dibandingkan dengan campuran aspal lain. Dengan demikian jelas bahwa agregat halus khususnya filler sangat menentukan kinerja dari campuran HRS.

Stabilitas campuran Hot Rolled Sheet menurut Zamhari (1984) bergantung pada stiffness dari mortar campuran yang merupakan korelasi antara proporsi mortar dalam campuran dan diskontinuitas dari gradasinya dengan cara saling mengunci antar agregat halusnya. Kedudukan dari agregat kasar seolah-olah mengambang di dalam mortar, sehingga deformasi yang terjadi adalah deformasi pada mortarnya.

Di Indonesia HRS dikenal dengan Lataston (Lapis Tipis Aspal Beton), dengan spesifikasi gradasi yang dikeluarkan oleh Departemen Kimpraswil seperti Tabel 1 dan Ketentuan sifat-sifat campuran seperti Tabel 3. Karakteristik yang terpenting pada campuran ini adalah durabilitas, dan fleksibilitas.

Sesuai fungsinya lataston mempunyai 2 macam campuran yaitu :

a. Lataston sebagai lapisan aus, dikenal dengan nama HRS-WC (Hot Rolled Sheet-Wearing Coarse). Tebal nominal minimum adalah 3 $\mathrm{cm}$

b. Lataston sebagai lapisan pondasi, dikenal dengan nama HRS-Base, dengan tebal nominal minimum adalah $3,5 \mathrm{~cm}$.

Tabel 1. Gradasi Agregat Untuk Campuran Aspal

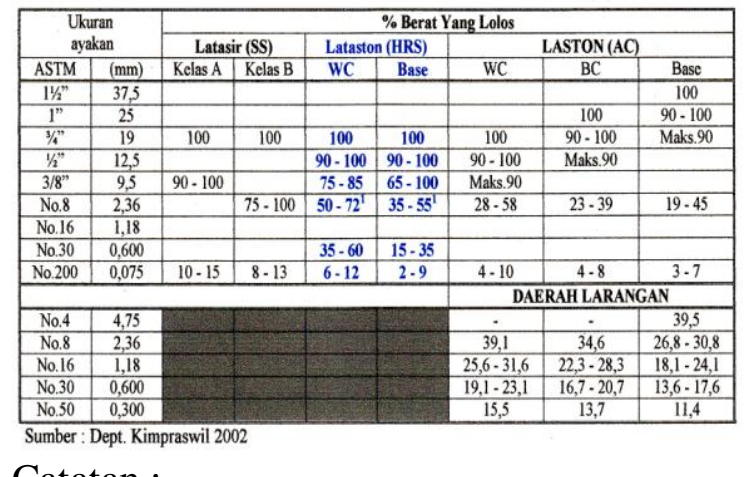

Catatan :

a. Untuk HRS-WC dan HRS-Base, paling sedikit $80 \%$ agregat lolos ayakan No.8 $(2,36 \mathrm{~mm})$ harus juga lolos ayakan No.30 $(0,600 \mathrm{~mm})$. Lihat contoh batasbatas "bahan bergradasi senjang" yang lolos ayakan No.8 (2,36 mm) dan tertahan ayakan No.30 (0,600 mm) dalam Tabel 2.

b. Untuk AC, digunakan titik kontrol gradasi agregat, berfungsi sebagai batas-batas rentang utama yang harus 
ditempati oleh gradasi-gradasi tersebut. Batas-batas gradasi ditentukan pada ayakan ukuran nominal maksimum, ayakan menengah $(2,36 \mathrm{~mm})$ dan ayakan terkecil $(0,075 \mathrm{~mm})$.

Tabel 2. Contoh Batas-batas "Bahan bergradasi senjang"

\begin{tabular}{|c|c|c|c|c|}
\hline$\%$ lolos No.8 & $\overline{40}$ & 50 & 60 & 70 \\
\hline \%lolos No.30 & Paling sedikit 32 & Paling sedikit 40 & Paling sedikit 48 & Paling sedikit 56 \\
\hline \%kesenjangan & 8 atau kurang & 10 atauk kurang & 12 ataukurang & 14 atau kurang \\
\hline
\end{tabular}

Tabel 3. Ketentuan Sifat-sifat Campuran

\begin{tabular}{|c|c|c|c|c|c|c|c|c|}
\hline \multirow{2}{*}{\multicolumn{2}{|c|}{ Sifat-sifat Campuran }} & & Latasir & Lata & & & Lasto & \\
\hline & & & $\begin{array}{c}\text { Kelas A } \\
\& B\end{array}$ & & Base & WC & $\mathrm{BC}$ & Base \\
\hline \multicolumn{2}{|c|}{ Penyerapan kadar aspal } & Maks. & & \multicolumn{5}{|c|}{$\begin{array}{l}1,2 \text { untuk Lalu Lintas }>1.0000 .000 \text { ESA } \\
1,7 \text { untuk Lalu Lintas }<1.000 .000 \text { ESA }\end{array}$} \\
\hline \multicolumn{2}{|c|}{ Jumlah tumbukan per bidang } & & 50 & \multirow{2}{*}{\multicolumn{2}{|c|}{5}} & \multirow{2}{*}{\multicolumn{3}{|c|}{$\frac{4.9}{59}$}} \\
\hline \multirow{4}{*}{$\begin{array}{l}\text { Rongga dalam } \\
\text { campuran (\%) } \\
(4)\end{array}$} & $\begin{array}{l}\text { Lalu Lintas (LL) } \\
>1 \text { juta ESA }\end{array}$ & $\frac{\text { Min. }}{\text { Maks. }}$ & \multirow{3}{*}{$\begin{array}{c}\text { Tidak } \\
\begin{array}{c}\text { digunakan } \\
\text { untuk LL } \\
\text { berat }\end{array} \\
\end{array}$} & & & & & \\
\hline & $>0,5$ juta ESA \& < & Min. & & \multicolumn{2}{|c|}{4.0} & \multicolumn{3}{|c|}{3.9} \\
\hline & 1 juta ESA & Maks. & & 6. & & & 4.9 & \\
\hline & $\begin{array}{l}\text { Lalu Lintas (LL) } \\
<0,5 \text { juta ESA }\end{array}$ & Min. & \multicolumn{3}{|c|}{$\frac{3.0}{6.0}$} & \multicolumn{3}{|c|}{$\frac{3.0}{50}$} \\
\hline \multicolumn{2}{|c|}{$\begin{array}{l}<<0,5 \text { juta ESA } \\
\text { Rongga dalam Agregat (VMA) (\%) }\end{array}$} & Masin. & \multicolumn{3}{|c|}{6.0} & \multicolumn{3}{|c|}{5.0} \\
\hline \multirow{3}{*}{$\begin{array}{l}\text { Rongga terisi } \\
\text { aspal (\%) }\end{array}$} & $\begin{array}{l}\text { Lalu Lintas (LL) } \\
>1 \text { juta ESA }\end{array}$ & Min. & \multirow{2}{*}{$\begin{array}{c}\text { Tidak } \\
\text { digunakan } \\
\text { untuk LL } \\
\text { berat } \\
\end{array}$} & \multicolumn{2}{|l|}{65} & 65 & \multirow[t]{2}{*}{$\frac{14}{63}$} & \multirow[t]{2}{*}{$\begin{array}{l}13 \\
60\end{array}$} \\
\hline & $\begin{array}{c}>0,5 \text { juta ESA \& \& } \\
1 \text { juta ESA }\end{array}$ & Min. & & \multicolumn{3}{|r|}{68} & & \\
\hline & $\begin{array}{l}\text { Lalu Lintas (LL) } \\
<05 \text { juta ESA }\end{array}$ & Min. & \multicolumn{5}{|c|}{75} & 73 \\
\hline \multicolumn{2}{|c|}{ Stabilitas Marshall (kg) } & Min & 200 & \multicolumn{4}{|c|}{800} & $800^{(1)}$ \\
\hline \multirow{2}{*}{\multicolumn{2}{|c|}{ Kelelehan (mm) }} & $\begin{array}{l}\text { Maks. } \\
\text { Min }\end{array}$ & $\frac{850}{2}$ & \multirow{2}{*}{\multicolumn{4}{|c|}{2}} & $2^{(i)}$ \\
\hline & & Maks, & & & & & & \\
\hline \multirow{2}{*}{\multicolumn{2}{|c|}{ 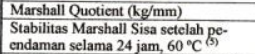 }} & Min. & & & 20 & & & 200 \\
\hline & & Min. & \multicolumn{6}{|c|}{$\begin{array}{l}85 \text { untuk Lalu Lintas }>1.000 .000 \text { ESA } \\
80 \text { untuk Lalu Lintas }<1.000 .000 \text { ESA }\end{array}$} \\
\hline \multirow{3}{*}{$\begin{array}{l}\text { Rongga dlm } \\
\text { campuran (\%) } \\
\text { pada } \\
\text { Kepadatan } \\
\text { membal } \\
\text { (refusal) }\end{array}$} & $\begin{array}{l}\text { Lalu Lintas (LL) } \\
>1 \text { juta ESA }\end{array}$ & $\begin{array}{l}\text { Min. } \\
\text { Maks. }\end{array}$ & \multirow{2}{*}{$\begin{array}{c}\text { Tidak } \\
\text { digunakan } \\
\text { untuk LL } \\
\text { berat }\end{array}$} & Laru & & & \multicolumn{2}{|c|}{2,5} \\
\hline & $\begin{array}{l}>0,5 \text { juta ESA \& }< \\
1 \text { juta ESA }\end{array}$ & $\begin{array}{l}\text { Min } \\
\text { Maks. }\end{array}$ & & \multicolumn{5}{|c|}{2} \\
\hline & $\begin{array}{l}\text { Lalu Lintas (LL) } \\
<0,5 \text { juta ESA }\end{array}$ & $\begin{array}{l}\text { Min. } \\
\text { Maks. }\end{array}$ & \multicolumn{6}{|c|}{1} \\
\hline
\end{tabular}

\section{c. Agregat}

Agregat atau granular material adalah material berbutir yang keras dan kompak. Agregat yang dipakai sebagai bahan perkerasan jalan meliputi antara lain batu bulat, batu pecah, pasir dan filler atau abu batu. Agregat mempunyai peranan yang sangat penting dalam perkerasan jalan, karena jumlah yang dibutuhkan dalam campuran perkerasan umumnya berkisar antara 90\%-95\% dari berat total campuran, atau $75 \%-85 \%$ dari volume campuran (The Asphalt Institute, 1983). Agregat berperan penting terhadap daya dukung perkerasan jalan, yang sebagian besar ditentukan oleh karakteristik agregat yang digunakan. Totomihardjo (1995), secara umum agregat sebagai bahan jalan harus memenuhi persyaratan :

a. Tahan lama (durable), resistance to abrasive wear. b. Kuat (strong), resistance to slow or rapid loading.

c. Ulet (toughness), agregat harus memiliki keuletan yang cukup, akan memberikan tahanan terhadap slow crushing load dan rapid impact load.

d. Keras (hardness), akan memberikan tahanan terhadap abrational attrition.

e. Polishing, agregat harus memiliki tahanan terhadap polishing agar menyediakan koefisien gesek yang cukup dan tahan lama.

f. Stripping, agar agregat tahan terhadap stripping harus mempunyai adhesi yang baik dengan bahan ikatnya

g. Weathering, agregat harus memiliki ketahanan terhadap cuaca (weather) antara lain terhadap perubahan suhu, air, kembang susut dan frost.

\section{d. Filler}

Fungsi dari bahan filler (pengisi) adalah untuk mengurangi kepekaan campuran terhadap temperatur. Penggunaan bahan pengisi harus dibatasi, jika terlalu banyak menyebabkan campuran getas dan mudah retak akibat beban lalu lintas. Sebaliknya jika terlalu rendah akan menghasilkan campuran lunak dan tidak tahan cuaca. Bahan filler adalah suatu material halus yang minimal $65 \%$ lolos saringan No.200 berdasarkan spesifikasi Bina Marga atau minimal $85 \%$ lolos saringan $0,075 \mathrm{~mm}$ berdasarkan spesifikasi British standard. Bahan pengisi dapat terdiri dari debu batu kapur (lime stone Dust), abu batu, semen portland, abu terbang (fly ash) atau bahan non plastis lainnya (Dept. Kimpraswil 2004)

Fungsi dari filler dalam campuran, pertama memodifikasi gradasi agregat halus. Kedua filler bersama-sama aspal membentuk adukan sebagai pelumas dan mengikat agregat halus pada adukan. Partikel filler mengisi ruang antara agregat halus dan kasar serta memberikan konstribusi untuk meningkatkan kepadatan. Filler juga berpengaruh pada kadar aspal optimum melalui luas permukaan dari 
partikel mineral. Sifat-sifat dari permukaan partikel filler memperlihatkan modifikasi sifat-sifat reologi terhadap aspal contohnya pada penetrasi, daktilitas dan ketahanan campuran terhadap retak.

\section{e. Aspal}

Aspal adalah suatu material yang berwarna hitam atau coklat tua yang bersifat termoplastis. Pada temperatur ruang berbentuk padat sampai semi padat. Jika dipanaskan sampai suatu temperatus tertentu aspal dapat menjadi lunak atau cair, sehingga aspal dapat membungkus agregat pada saat pembuatan campuran. Pada sat temperaturnya turun kembali menuju suhu ruang, aspal akan menjadi keras dan mengikat agregat di tempatnya. Aspal juga berfungsi sebagai pengisi rongga antara butir-butir agregat dan pori-pori yang ada dari agregat. Aspal harus mempunyai sifat adhesi dan kohesi yang baik dan memberikan sifat fleksibel pada campuran. Selain itu aspal juga membuat permukaan jalan menjadi kedap. Sebagai salah satu material konstruksi perkerasan lentur, aspal merupakan salah satu komponen kecil yang umumnya hanya $4-10 \%$ atau $10-15 \%$ volume, namun merupakan komponen yang relatif mahal harganya.

Beberapa persyaratan aspal sebagai bahan jalan adalah sebagai berikut :

a. Kekakuan / kekerasan / Stiffness.

Setelah berfungsi sebagai bahan jalan aspal yang dipilih harus mempunyai stiffness yang cukup.

b. Sifat mudah dikerjakan / Workability.

Aspal yang dipilih haruslah mempunyai workability yang cukup dalam pelaksanaan pekerjaan pengaspalan. Hal ini akan memudahkan pelaksanaan penghamparan bahan tersebut dan juga memudahkan dalam memadatkan untuk memperoleh lapis yang padat kompak.

Dari sudut workability ini usaha yang dapat dilakukan adalah :

1. Pemanasan / heating.

2. Ditambah pengencer.

3. Ditambah bahan pengelmusi.

\section{f. Abu Tanah Liat Bakar}

Abu tanah liat bakar dalam hal ini merupakan abu yang diperoleh dari pembakaran tanah liat (clay) dengan proses yang sederhana seperti proses pembakaran bata yang terbuat dari tanah liat. Kalau proses pembuatan bata terdapat beberapa tahapan mulai dari persiapan bahan, pemeraman, pembentukan, pengeringan dan penyusunan dalam tungku, pembakaran sehingga diperoleh bata siap pakai. Proses pembakaran bata tersebut pada temperatur tinggi maka sifat tanah liat sebagai bahan dasar bata akan mengalami perubahan sebagai berikut :

1. Pada temperatur $150^{\circ} \mathrm{C}$ semua air pembentuk dan yang ditambahkan pada tanah liat akan menguap.

2. Pada temperatur $400{ }^{\circ} \mathrm{C}-600{ }^{0} \mathrm{C}$ air yang terikat secara kimia dan zat lain di dalam tanah liat akan menguap.

3. Pada temperatur di atas $800^{\circ} \mathrm{C}$ terjadi perubahan menjadi padat dan kuat.

4. Senyawa besi yang terdapat pada tanah liat akan berubah menjadi stabil dan umumnya akan memberikan warna merah.

Dari proses tersebut maka sifat plastis pada tanah liat akan hilang, dan selanjutnya dengan proses penggilingan sederhana dapat diperoleh butiran halus. Untuk mendapatkan filler maka dilakukan penyaringan dengan saringan No. 200

\section{g. Uji Empirik Marshall}

Pengujian Marshall menghasilkan parameter-parameter yang disebut Marshall Properties, dan terdiri dari density (gr/cc), Void in The Mix (VIM), Void Filled With Asphalt (VFWA), stabilitas (kg), flow (mm).

Dua sifat yang dapat dijelaskan adalah : beban maksimum yang dapat dipikul oleh benda uji sebelum runtuh disebut Marshall Stabilty dan besarnya perubahan bentuk benda uji sebelum runtuh dinamakan Marshall Flow. Perbandingan antara stability dan flow disebut Marshall 
Quotient, serupa dengan kekakuan yang merupakan ketahanan material terhadap perubahan bentuk..

\section{h. Kadar Aspal Dalam Campuran}

Aspal dalam campuran berfungsi sebagai bahan ikat antar agregat. Aspal sebagai hasil alam maupun hasil dari penyaringan minyak kasar, mempunyai sifat-sifat yang tersendiri. Pemakaian aspal dalam campuran sangat menentukan tingkat kekedapan terhadap air dan udara. Semakin banyak aspal akan semakin rapat campuran, karena rongga campuran dapat terisi oleh aspal. Sebaliknya bila kadar aspal terlalu kecil, maka banyak rongga yang kosong, sehingga campuran kurang rapat. Pemakaian aspal yang banyak juga akan mempertinggi durabilitas.

Selain berpengaruh terhadap kekedapan kadar aspal berpengaruh juga terhadap kekakuan campuran (stiffness). Mula-mula kekakuan meningkat dengan bertambahnya jumlah aspal, sampai keadaan maksimum, selanjutnya jika jumlah aspal terus ditambah kekakuan menurun. Kekakuan campuran maksimum cenderung terjadi pada kadar aspal optimum (C.L. Monismith, 1984).

Dalam merencanakan suatu campuran aspal beton perlu dilakukan beberapa percobaan laboratorium. Pemeriksaan laboratorium meliputi pemeriksaan bahan seperti aspal, bahan agregat dan pemeriksaan campuran. Pemeriksaan mengenai aspal dan agregat telah dibahas pada Bab mengenai aspal dan agregat, sedangkan di sini selanjutnya akan dibahas mengenai pemeriksaan campuran keduanya saja sebagai campuran beraspal untuk bahan perkerasan jalan.

Tahapan yang perlu diketahui dalam perencanaan suatu campuran beraspal antara lain :

a. Melakukan pemeriksaan terhadap aspal yang akan dipakai. Macam pemeriksaan yaitu menentukan viskositas dan berat jenis aspal. Viskositas diperlukan guna menentukan suhu campuran maupun suhu pemadatan.

b. Menentukan spesifikasi gradasi agregat yang akan dipakai, yaitu suatu besaran prosentase agregat yang lewat suatu saringan dengan ukuran tertentu. Banyak macam spesifikasi agregat yang dipakai dalam perkerasan jalan sesuai dengan kebutuhan.

c. Melakukan pemeriksaan mutu agregat yang akan dipakai.

d. Menentukan kombinasi beberapa fraksi agregat sehingga mendapatkan gradasi campuran yang memenuhi spesifikasi yang ditentukan, karena pada umumnya agregat yang akan dipakai terdiri dari beberapa fraksi.

e. Jika mutu bahan sudah terpenuhi dan harga viskositas dari aspal serta kombinasi fraksi sudah diketahui, kemudian dibuat campuran agregat dengan berbagai kadar aspal. selanjutnya dilakukan percobaan Marshall guna menentukan flow dan stabilitas campuran beraspal.

Syarat-syarat utama aspal beton yang bermutu baik adalah :

a. Campuran harus mempunyai nilai stabilitas yang cukup, yaitu harus sanggup menahan beban lalu lintas tanpa terjadinya deformasi dalam bentuk jejak roda (rutting) atau rusak bergelombang akibat dorongan beban roda kendaraan (pushing).

b. Campuran tidak boleh retak-retak, artinya harus mampu menahan lendutan (deflection), yang mungkin timbul terhadap lapisan hamparan atau permukaan tanpa mengalami kerusakan.

c. Campuran harus dapat bertahan lama (durable), artinya tidak rusak atau aus di bawah beban lalu lintas dan kondisi cuaca yang ada.

d. Campuran harus cukup kekasarannya (skid resistance), dan harus tetap seperti sedemikian selama masa pelayanannya.

e. Harus cukup ekonomis dalam artian murah namun kuat. 
Sesuai dengan latar belakang dan permasalahan yang dihadapi maka tujuan dan sasaran serta hasil dari kegiatan ini dapat dirinci sebagai berikut :

\section{Tujuan}

Melakukan studi untuk mengupayakan penggunaan abu tanah liat bakar sebagai material filler pada campuran beraspal perkerasan jalan melalui penelitian kinerja laboratorium yang dihasilkan dari campuran tersebut.

\section{Sasaran}

a. Mengurangi pemakaian dan ketergantungan material abu batu dalam konstruksi perkerasan jalan, sehingga dapat menghemat biaya pekerjaan konstruksi jalan raya.

b. Memanfaatkan material lokal untuk bahan konstruksi jalan, sehingga dapat meningkatkan upaya penggunaan sumber daya alam yang tersedia serta secara umum dapat meningkatkan pendapatan daerah.

\section{Konstribusi Penelitian :}

Konstribusi penelitian mengarah kepada pengembangan ilmu pengetahuan teknologi (Kategori Penelitian I) yaitu untuk memperoleh data teknis material lokal yang memenuhi spesifikasi untuk campuran beraspal kontruksi jalan, serta sebagai rekomendasi teknis dalam pekerjaan konstruksi jalan raya di daerah Sumatera Barat pada umumnya.

\section{METODOLOGI}

\section{a. Waktu dan Tempat Penelitian :}

Kegiatan ini diperkirakan membutuhkan waktu sekitar 8 bulan yang dilakukan di laboratorium Transportasi, Jurusan Teknik Sipil Politeknik Negeri Padang dan tempat terkait lainnya jika diperlukan.

\section{b. Bahan dan Alat :}

Pengujian yang berhubungan dengan komponen individu dari material penyusun campuran HRS-WC akan dilakukan sesuai kebutuhan. Material yang digunakan dalam penelitian meliputi :

- Agregat : Agregat standar digunakan kerikil batu pecah dari stone crusher produksi PT. Statika Mitra Sarana yang berlokasi di Sicincin Padang Pariaman.

- Aspal : Aspal yang digunakan disesuaikan dengan daerah Sumatera Barat yaitu aspal Penetrasi 60/70 produksi Pertamina.

- Filler : Filler standar akan digunakan abu batu produksi dari PT. Statika Mitra Sarana Sicincin. Filler sebagai bahan pengujian merupakan abu tanah liat bakar yang berasal dari bukit Gunung Sarik Padang,

\section{c. Metodologi Pendekatan}

Kegiatan penelitian ini akan dilakukan menurut diagram rencana kerja seperti terlihat pada Gambar 1.

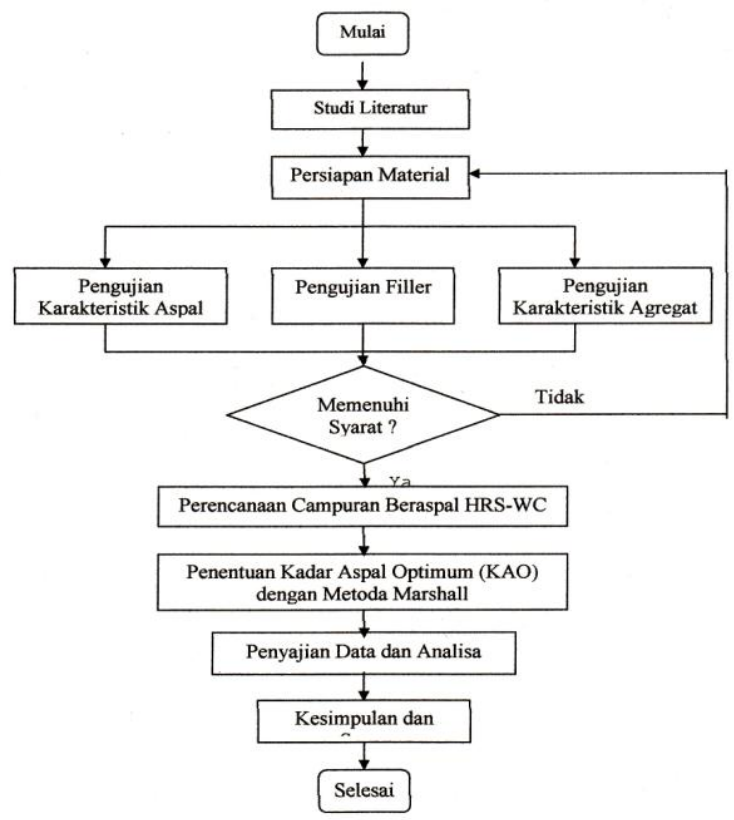

Gambar 1. Diagram Rencana Kerja

\section{d. Lingkup Pekerjaan Penelitian}

Adapun lingkup pekerjaan ini adalah sebagai berikut :

a. Pengetesan karakteristik material agregat dan aspal menggunakan aturan SNI (Standard Nasional Indonesia) 
b. Spesifikasi campuran beton aspal mengikuti gradasi untuk campuran HRS-WC Spesifikasi Bina Marga.

c. Aspal yang digunakan adalah pen 60/70

d. Perencanaan campuran dan penentuan KAO dengan metoda Marshall.

\section{e. Pengujian pada Agregat dan Filler}

Adapun pengujian yang akan dilakukan terhadap agregat kasar, agregat halus dan filler meliputi pengujianpengujian seperti tercantum pada Tabel 4.

Tabel 4. Standar Pengujian Agregat

\begin{tabular}{|c|c|}
\hline \multicolumn{2}{|l|}{ Pengujian Agregat Kasar : } \\
\hline Jenis Pengujian & Standar Pengujian \\
\hline $\begin{array}{l}\text { - Berat jenis } \\
\text { - Penyerapan terhadap air } \\
\text { - Keausan dengan Los Angeles } \\
\text { - Kelekatan terhadap aspal } \\
\text { - Nilai tumbukan } \\
\text { - Nilai tekanan }\end{array}$ & \begin{tabular}{l|} 
SNI 03-1969-1990 \\
SNI 03-1969-1990 \\
SNI 03-2417-1991 \\
SNI 03-2439-1991 \\
SNI 03-4426-1997 \\
SNI 03-2417-1991
\end{tabular} \\
\hline \multicolumn{2}{|l|}{ Pengujian Agregat Halus : } \\
\hline Jenis Pengujian & Standar Pengujian \\
\hline $\begin{array}{l}\text { - Berat jenis } \\
\text { - Penyerapan terhadap air }\end{array}$ & $\begin{array}{l}\text { SNI 03-1970-1990 } \\
\text { SNI 03-1970-1990 }\end{array}$ \\
\hline
\end{tabular}

Bahan Filler yang akan digunakan adalah abu batu standard an abu tanah liat bakar dari lokasi bahan sumber penelitian. Adapun pengujian yang akan dilakukan terhadap filler hanya pengujian berat jenis sesuai dengan SNI 15-2531-1991 dan SNI 1970 - 1990

\section{f. Pengujian pada Aspal}

Aspal yang akan digunakan adalah Pen 60/70 produksi Pertamina, dimana standar pengujian yang dilakukan seperti yang tercantum pada Tabel 5.

Tabel 5. Standar Uji Aspal Pen 60/70

\begin{tabular}{|l|c|c|c|}
\hline \multirow{2}{*}{ Jenis Pemeriksaan } & \multirow{2}{*}{ Standar Pengujian } & \multicolumn{2}{c|}{ Batasan } \\
\cline { 3 - 4 } & & Min. & Maks. \\
\hline Penetrasi $\left(25^{\circ} \mathrm{C}, 100 \mathrm{gr}, 5\right.$ detik $)$ & SNI 06-2456-1991 & 60 & 79 \\
\hline Titik Lembek (Ring and Ball) & SNI 06-2434-1991 & $48^{\circ} \mathrm{C}$ & $58^{\circ} \mathrm{C}$ \\
\hline Titik Nyala (Cleveland Open Cup) & SNI 06-2433-1991 & $200^{\circ} \mathrm{C}$ & - \\
\hline Kelarutan & AASHTO T-44-90 & $99 \%$ & - \\
\hline Daktilitas $\left(25^{\circ} \mathrm{C}, 5 \mathrm{~cm} /\right.$ menit $)$ & SNI 06-2432-1991 & $100 \mathrm{~cm}$ & - \\
\hline Berat Jenis $\left(25^{\circ} \mathrm{C}\right)$ & SNI 06-2441-1991 & 1 & - \\
\hline
\end{tabular}

\section{g. Prosedur Laboratorium}

1) Rancangan Campuran

Rancangan campuran HRS -WC pada penelitian ini mengikuti spesifikasi campuran beraspal panas dengan gradasi ideal (gradasi tengah) yang dikeluarkan oleh Departemen Kimpraswil tahun 2002.

Berdasarkan SNI 06-2489-1991, pengujian Marshall dilakukan dengan kondisi sebagai berikut :

- Temperatur agregat $\pm 160^{\circ} \mathrm{C}$

- Temperatur bahan pengikat $\pm 155^{\circ} \mathrm{C}$

- Temperatur Pemadatan $\pm 155^{\circ} \mathrm{C}$

- Jumlah tumbukan 2 x 75 tumbukan (lalin berat)

- Waktu pendinginan 18-60 jam

- Waktu perendaman pada $60^{\circ} 45-60$ menit

- Temperatur pengujian $60^{\circ} \mathrm{C}$

2) Pengujian Marshall

Pengujian dan analisis yang akan dilakukan terhadap benda uji Marshall secara detail mengikuti prosedur SNI 062489-1991. Dalam menentukan kadar aspal optimum, disiapkan tiga benda uji untuk lima kadar aspal. variasi kadar aspal yang dipilih yaitu antara 5\% sampai $9 \%$ terhadap berat total campuran agregat, dengan selang kenaikan $1 \%$. dimana aspal yang digunakan penetrasi 60/70 yang merupakan produksi Pertamina.

Sebelum pengujian dengan alat Marshall, setiap benda uji direndam dalam bak perendam pada temperatur $60^{\circ}$ selama 45 menit, setelah itu baru dilakukan pengujian dengan jalan melakukan pembebanan dengan alat uji Marshall . 
Beban maksimum yang dipikul oleh benda uji pada kondisi diukur, dan nilainya disebut dengan stabilitas dari benda uji. Sedangkan deformasi yang terjadi pada kondisi beban maksimum, disebut dengan nilai kelelehan dari benda uji.

Tabel 6. Model benda uji Marshall

\begin{tabular}{|c|c|c|c|c|c|c|}
\hline \multirow[b]{2}{*}{ Variasi Kadar Filler } & \multicolumn{5}{|c|}{ Kadar Aspal } & \multirow{2}{*}{$\begin{array}{c}\text { Total } \\
\text { benda } \\
\text { Uji }\end{array}$} \\
\hline & $5,0 \%$ & $\begin{array}{l}6,0 \\
\% \\
\end{array}$ & $7,0 \%$ & $8,0 \%$ & $9,0 \%$ & \\
\hline Standar & $3 \mathrm{~s}$ & $3 \mathrm{~s}$ & $3 \mathrm{~s}$ & $3 \mathrm{~s}$ & $3 \mathrm{~s}$ & \multirow{5}{*}{75 buah } \\
\hline $25 \%$ Abu tanah liat & $3 \mathrm{~s}$ & $3 \mathrm{~s}$ & $3 \mathrm{~s}$ & $3 \mathrm{~s}$ & $3 \mathrm{~s}$ & \\
\hline $50 \%$ Abu tanah liat & $3 \mathrm{~s}$ & $3 \mathrm{~s}$ & $3 \mathrm{~s}$ & $3 \mathrm{~s}$ & $3 \mathrm{~s}$ & \\
\hline $75 \%$ Abu tanah liat & $3 \mathrm{~s}$ & $3 s$ & $3 \mathrm{~s}$ & $3 \mathrm{~s}$ & $3 \mathrm{~s}$ & \\
\hline $100 \%$ Abu tanah liat & $3 \mathrm{~s}$ & $3 s$ & $3 \mathrm{~s}$ & $3 \mathrm{~s}$ & $3 \mathrm{~s}$ & \\
\hline
\end{tabular}

Keterangan : $3 s=$ tiga sampel

\section{h. Indikator kinerja}

Kegiatan penelitian ini merupakan kajian di laboratorium dengan mengamati perbandingan karakteristik teknik dari campuran HRS-WC yang menggunakan filler abu tanah liat baker dengan campuran HRS-WC yang menggunakan filler standar abu batu.

\section{HASIL DAN PEMBAHASAN}

\section{a. Hasil Pengujian Karakteristik Agregat}

Untuk mengetahui karakteristik agregat kasar, agregat halus dan filler yang akan digunakan dalam campuran, dilakukan pengujian fisik yang hasilnya menunjukkan bahwa agregat yang diuji memenuhi syarat untuk campuran yang direncanakan.

Tabel 7. Karakateristik Agregat

\begin{tabular}{|c|c|c|c|c|}
\hline Jenis Pengujian & Metoda Pengujian & Satuan & Hasil & Spesifikasi \\
\hline \multicolumn{5}{|l|}{ Agregat Kasar : } \\
\hline $\begin{array}{l}\text { - Berat Jenis Bulk } \\
\text { - Berat Jenis SSD } \\
\text { - Berat Jenis Semu } \\
\text { - Penyerapan Air } \\
\text { - Kelekatan Aspal } \\
\text { - Keausan dengan mesin LA } \\
\text { - Uji Tekanan }\end{array}$ & $\begin{array}{l}\text { SNI 03-1969-1990 } \\
\text { SNI 03-1969-1990 } \\
\text { SNI 03-1969-1990 } \\
\text { SNI 03-1969-1990 } \\
\text { SNI 03-2439-1991 } \\
\text { SNI 03-2417-1991 } \\
\text { SNI 03-2417-1991 }\end{array}$ & $\begin{array}{l}- \\
- \\
\\
\% \\
\% \\
\%\end{array}$ & \begin{tabular}{c|}
2,81 \\
2,92 \\
2,99 \\
2,09 \\
97 \\
13,58 \\
27,55
\end{tabular} & $\begin{array}{l}\text { Min. } 2,5 \\
\text { Min. } 2,5 \\
\text { Min. } 2,5 \\
\text { Maks. } 3 \\
\text { Min } 95 \\
\text { Maks. } 40 \\
\text { Maks. } 40\end{array}$ \\
\hline \multicolumn{5}{|l|}{ Agregat Halus : } \\
\hline $\begin{array}{l}\text { - Berat Jenis Bulk } \\
\text { - Berat Jenis SSD } \\
\text { - Berat Jenis Semu } \\
\text { - Penyerapan Air }\end{array}$ & $\begin{array}{l}\text { SNI 03-1969-1990 } \\
\text { SNI 03-1969-1990 } \\
\text { SNI 03-1969-1990 } \\
\text { SNI 03-1969-1990 }\end{array}$ & $\begin{array}{l}- \\
- \\
-\end{array}$ & $\begin{array}{l}2,58 \\
2,60 \\
2,60 \\
0,67\end{array}$ & $\begin{array}{l}\text { Min. 2,5 } \\
\text { Min. 2,5 } \\
\text { Min. 2,5 } \\
\text { Maks. } 3\end{array}$ \\
\hline \multicolumn{5}{|l|}{ Bahan Pengisi (Filler) : } \\
\hline $\begin{array}{l}\text { - Berat Jenis Bulk } \\
\text { - Berat Jenis SSD } \\
\text { - Berat Jenis Semu } \\
\text { - Penyerapan Air }\end{array}$ & $\begin{array}{l}\text { SNI 03-1969-1990 } \\
\text { SNI 03-1969-1990 } \\
\text { SNI 03-1969-1990 } \\
\text { SNI 03-1969-1990 }\end{array}$ & $\begin{array}{l}- \\
- \\
-\end{array}$ & $\begin{array}{l}2,56 \\
2,61 \\
2,71 \\
2,02\end{array}$ & $\begin{array}{l}\text { Min. 2,5 } \\
\text { Min. 2,5 } \\
\text { Min. 2,5 } \\
\text { Maks. } 3\end{array}$ \\
\hline
\end{tabular}

\section{b. asil Pengujian Karakteristik Aspal}

Dalam penelitian ini sebagai bahan pengikat aspal digunakan jenis aspal keras (AC) penetrasi 60-70 produksi pertaminia.. Hasil yang diperoleh menunjukkan bahwa aspal keras yang digunakan memenuhi syarat secara keseluruhan dari parameter yang diuji.(Tabel)

Tabel 8. Karakteristik Aspal

\begin{tabular}{|l|c|c|c|c|}
\hline \multicolumn{1}{|c|}{ Jenis Pengujian } & Metoda Pengujian & Satuan & Hasil & Spesifikasi \\
\hline Penetrasi $\left(25^{\circ} \mathrm{C}, 100 \mathrm{gr}, 5\right.$ detik $)$ & SNI 06-2456-1991 & $\mathrm{mm}$ & 76 & $60-79$ \\
\hline Titik Lembek (Ring and Ball) & SNI 06-2434-1991 & ${ }^{\circ} \mathrm{C}$ & 49 & $48-58$ \\
\hline Titik Nyala (Cleveland Open Cup) & SNI 06-2433-1991 & ${ }^{\circ} \mathrm{C}$ & 352 & Min. 200 \\
\hline Daktilitas $\left(25^{\circ} \mathrm{C}, 5 \mathrm{~cm} /\right.$ menit) & SNI 06-2432-1991 & $\mathrm{cm}$ & $>100$ & Min. 100 \\
\hline Berat Jenis $\left(25^{\circ} \mathrm{C}\right)$ & SNI 06-2441-1991 & - & 1,017 & Min. 1 \\
\hline
\end{tabular}

\section{c. Hasil Pengujian Marshall}

Nilai Kadar Aspal Optimum (KAO) dan Karakteristik Marshall pada KAO dapat dilihat pada Tabel 9.

Tabel 9. Karakteristik Marshall

\begin{tabular}{|c|c|c|c|c|c|c|c|c|c|}
\hline & Jenis Campuran & $\begin{array}{l}\text { KAO } \\
(\%)\end{array}$ & $\begin{array}{c}\text { Stabili } \\
\text { tas } \\
(\mathrm{Kg})\end{array}$ & $\begin{array}{l}\text { Density } \\
\text { (grimi) }\end{array}$ & VIM & $\begin{array}{l}\text { VMA } \\
(\%)\end{array}$ & $\begin{array}{l}\text { VFB } \\
\text { (\%) }\end{array}$ & $\begin{array}{l}\text { Flow } \\
(\mathrm{mm})\end{array}$ & $\begin{array}{c}\text { MQ } \\
\text { (Kg/mm) }\end{array}$ \\
\hline 1. & $\begin{array}{l}\text { Campuran HRS - WC } \\
\text { Dengan Filler Standar }\end{array}$ & 6,85 & 830 & 2,295 & 3,8 & 18,40 & 79 & 3.45 & 242 \\
\hline 2. & $\begin{array}{l}\text { Campuran HRS - WC } \\
\text { Dgn Filler } 25 \% \text { TLB }\end{array}$ & 6,90 & 840 & 2,295 & 3,7 & 18,45 & 80 & 3.47 & 242 \\
\hline 3. & $\begin{array}{l}\text { Campuran HRS - WC } \\
\text { Dgn Filler 50\% TLB }\end{array}$ & 6,95 & 845 & 2,295 & 3,7 & 18,50 & 80 & 3.48 & 242 \\
\hline 4. & $\begin{array}{l}\text { Campuran HRS - WC } \\
\text { Dgn Filler } 75 \% \text { TLB }\end{array}$ & 6,90 & 840 & 2,295 & 3,7 & 18,45 & 79 & 3,48 & 242 \\
\hline 5. & $\begin{array}{l}\text { Campuran HRS - WC } \\
\text { Dgn Filler 100\% TLB }\end{array}$ & 6,80 & 830 & 2,294 & 3,8 & 18,40 & 78 & 3,48 & 242 \\
\hline
\end{tabular}

\section{d. Analisis Sifat Marshall}

Berdasarkan analisis sifat Marshall yang dilakukan, maka Marshall Propertiesnya (density, VIM, VMA, VFB, stabilitas, Flow dan MQ ) menunjukkan nilai atau parameter marshall yang tidak signifikan jauh berbeda antara campuran standar dengan campuran subtitusi filler tanah liat bakar.

Secara umum nilai kadar aspal optimum (KAO) bervariasi antara 6,80\% sampai $6,95 \%$. 


\section{SIMPULAN}

\section{a. Kesimpulan}

Dari hasil penelitian yang dilakukan terhadap campuran HRS-WC dengan subtitutisi filler standar menggunakan filler tanah liat bakar asal Gunung Sarik Padang, diperoleh kesimpulan bahwa campuran beraspal yang dihasilkan ternyata memenuhi syarat spesifikasi sebagai bahan perkerasan jalan.

\section{b. Saran}

1. Pada penelitian ini jenis aspal yang digunakan hanya satu jenis yaitu AC pen 60/70 dengan variasi berbagai kadar aspal, selanjutnya perlu pemahaman lebih lanjut terhadap penggunaan aspal dengan penetrasi yang lebih rendah ataupun tinggi.

2. Penentuan modulus kekakuan aspal dan modulus kekakuan campuran dalam hal ini masih menggunakan metoda empirik, akan lebih memuaskan dan lebih baik kalau dilakukan dengan uji langsung menggunakan alat khusus seperti UMATTA atau UTM.

\section{DAFTAR PUSTAKA}

AASHTO,(1990),Standard Spesification for Transportation Materials and Methods of Sampling and Testing Materials, Part II Spesicification, $15^{\text {th }}$ Edition, AASHTO Pubilcation, Washington.

APRIZAL.,(2002), Pengaruh Penggunaan Filler Debu Batu dalam Campuran Beton Aspal Terhadap Sifat Marshall dan Modulus Resilient dengan Uji tarik tak Langsung beban statis. Tugas Akhir, Jurusan Teknik Sipil, FT UGM, Yogyakarta.

British Standard 594, (1992), Hot Rolled Asphalt For Roads and Other Paved Areas, part I. Spesification for Constituents of Asphalt Mixtures,
British Standards Institution, London 1992.

Departemen Pekerjaan Umum, (1989), SNI 03-1737-1989 ; SKBI-2.4.26.1987, Tata Cara Pelaksanaan Lapis Aspal Beton (LASTON) untuk Jalan Raya, Jakarta.

Departemen Pekerjaan Umum, (1991), SNI 06-2489-1991 Metode Campuran Aspal dengan Alat Marshall, Jakarta.

Departemen Pekerjaan Umum, (1994), SNI 03-3425-1994 Tata Cara Pelaksanaan lapis Tipis Aspal Beton untuk Jalan Raya, Jakarta.

Departemen Kimpraswil, Pusat Penelitian Dan Pengembangan Prasarana Transportasi (2002), Spesifikasi Campuran Beraspal Panas, Jakarta.

Kadir, Y., (2003). Pengaruh Jenis Filler terhadap Campuran Hot Rolled Sheet (HRS), Thesis Magister, Rekayasa Transportasi Teknik Sipil, Universitas Brawijaya Malang.

Pratomo, P., (2001), Penggunaan Limbah Abu (Marmer, Terbang, Sawit) Sebagai Bahan Pengisi Pada Campuran Lataston, Prosiding Simposium IV FSTPT Bali.

Yasruddin, (2000), Kinerja Laboratorium pada Hot Rolled Asphalt dengan Kandungan Batu Bata yang Dihaluskan Sebagai Filler, Magister Thesis, STJR, Institut Teknologi Bandung. 